\title{
The effect of evening light on circadian-related outcomes: A systematic review ${ }^{*}$
}

\author{
Mariève $\mathrm{Cyr}^{\dagger} \quad$ Despina Z. Artenie ${ }^{\ddagger} \quad$ Alain Al Bikaii§ \\ David Borsook $^{\mathbb{I}} \quad$ Jay A. Olson"l
}

\section{Summary}

Bright light exposure at night can help workers adapt to their shift schedules, but there has been relatively little research on evening light. We conducted a systematic review of studies that manipulated light exposure in the evening (broadly defined as 16:00 to 22:00) before real or simulated night shifts. Across the five eligible studies, evening light produced phase delays in melatonin, body temperature, and sleep propensity; it also improved sleep quality, sleep duration, memory, and work performance. There were mixed effects for mood, no changes in sleepiness, and no negative effects. The confidence in these results ranged from moderate for physiological markers of circadian phase delays to very low for mood. Future studies should compare the relative effectiveness and safety of evening versus night-time light exposure. Overall, the benefits of evening light for shift workers are tentative yet promising.

${ }^{*}$ Preprint of a manuscript published in Sleep Medicine Reviews at https:/ / doi.org/10.1016/j.smrv.2022.10 1660. Corresponding author: J. A. Olson (jay.olson@mail.mcgill.ca).

${ }^{\dagger}$ Faculty of Medicine and Health Sciences, McGill University, Montréal, QC, Canada

‡Department of Psychology, Université du Québec à Montréal, QC, Canada

$\S$ McGill University Health Centre, Montréal, QC, Canada

II Departments of Psychiatry and Radiology, Massachusetts General Hospital, Boston, MA, USA

" Department of Psychology, Harvard University, Cambridge, MA, USA 


\section{Keywords}

circadian rhythms, shift work, circadian misalignment, evening light, light exposure, light therapy

\section{Introduction}

Around a quarter of employees in North America ${ }^{1,2}$ and Europe ${ }^{3}$ are shift workers. Although working outside of typical daytime hours is often necessary, ${ }^{4}$ it has been linked to various negative effects. Shift workers often experience circadian misalignment, in which physiological rhythms deviate from the demands of the environment. ${ }^{5}$ In the short term, shift work and the resulting misalignment are associated with sleep deprivation, which can increase fatigue and sleepiness, impair cognition, reduce mood, and disturb metabolic function. ${ }^{6-10}$ Working at night additionally increases the risk of accidents at work ${ }^{11,12}$ and while driving. ${ }^{13,14}$ In the longer term, shift work is associated with a higher risk of health conditions, including cardiovascular disease, Type II diabetes, ischemic stroke, and cancer. ${ }^{7,15,16}$

\section{Light exposure at night}

Researchers have attempted to reduce some of these negative effects by targeting circadian disturbances. Bright light exposure at strategic times is one of the most effective ways to shift circadian rhythms and reduce misalignment. ${ }^{17,18}$ Light exposure modulates circadian rhythms through the central pacemaker in the suprachiasmatic nucleus of the hypothalamus. ${ }^{19}$ Bright light during the first half of the night followed by light avoidance in the morning can induce phase delays, in which circadian rhythms are shifted later to delay sleep times. Conversely, avoiding light at night followed by bright light exposure in the morning can induce phase advances, which promote earlier awakenings. ${ }^{5}$ The "crossover point" - when light exposure transitions from causing phase delays to phase 
advances - usually occurs near the body temperature minimum, around 2 to $3 \mathrm{~h}$ before the habitual wake time. ${ }^{20}$ Light exposure around this time is most effective at shifting circadian rhythms $s^{5,20,21}$ and is often used in interventions to reduce circadian misalignment in shift workers. ${ }^{22,23}$

These light-based interventions typically have two components: bright light exposure and light avoidance. A recent review of laboratory and field studies to promote phase delays in shift workers recommended bright light in the evening and night (18:00 to 04:00) along with light avoidance in the morning (06:00 to 09:00). ${ }^{17}$ Field studies combining these components have produced phase delays in body temperature, cortisol, and melatonin; improvements in sleep duration, cognitive performance, alertness, and mood; and reductions in insomnia and fatigue. ${ }^{23-26}$ These effects may be stronger in permanent night shift workers, who receive light exposure over several consecutive nights which leads to to greater phase delays. ${ }^{27}$ For rapidly rotating shift workers, who often alternate between day shifts and night shifts within the same week, partial circadian alignment may be possible and provide short-term benefits. ${ }^{25,28}$ Beyond these circadian effects, bright light exposure can also temporarily improve alertness and mood. ${ }^{19,29}$

\section{Potential downsides of light exposure at night}

Studies looking at phase delays typically use light exposure late at night, near the body temperature minimum. ${ }^{5}$ However, because this exposure period often takes place during the night shift, it may be less feasible at work. Interventions during work hours require institutional buy-in, which is often costly and slow. Some work environments may also be less suited to light exposure at night; in hospitals, for example, providing light exposure to shift workers could impair patients' sleep. ${ }^{30}$ Determining the optimal timing of light exposure presents additional concerns. ${ }^{31}$ Since the crossover point varies among individuals, ${ }^{32}$ the effect of the light exposure during the night can be hard to predict. For 
example, two workers with respective crossover points at 05:00 and 03:00 who receive light at 04:00 would shift in opposite directions; one would phase delay, becoming more aligned with the night shift schedule, while the other would phase advance, exacerbating circadian misalignment. Without individualised and feasible ways to estimate circadian phase, light exposure during the night shift may thus have unintended consequences.

Night-time light exposure also raises safety concerns. Accumulating evidence shows that receiving light at night may harm physical and psychological health. ${ }^{33-35}$ For example, it is a risk factor for obesity and cancer, ${ }^{33-35}$ with animal studies supporting these findings. ${ }^{34}$ Rodents show impaired glucose tolerance, ${ }^{36,37}$ increases in tumour growth, and slower responses to breast cancer treatments. ${ }^{38,39}$ Further, people living in areas with more night-time light exposure are more likely to have depressive symptoms and suicidal behaviour. ${ }^{40}$ Given the potential health risks of night-time light exposure, it is important to consider alternative strategies to reduce circadian misalignment in shift workers.

\section{Evening light as an alternative}

A more feasible and potentially safer alternative for permanent and rapidly rotating shift workers would be bright light during the evening rather than at night. Evening light exposure is easier to implement because it can take place before the night shift, thereby removing the need for institutional buy-in. Workers could use a portable light box at home or even get sunlight exposure on their way to work. Further, because the evening light occurs well before the crossover point, it is less likely to cause inadvertent phase advances.

However, it is unclear how effectively evening light can shift circadian rhythms. Circadian adaptation studies typically focus on night-time light exposure because it is the most effective at inducing rapid phase delays. If evening light elicits smaller delays, this could mean slower adaptation for permanent night shift workers. In contrast, compared to 
light at night, evening light may facilitate the transition back to day-oriented schedules, especially for rapidly rotating shift workers. In any case, current guidelines to reduce circadian misalignment often recommend night-time light exposure while evening light is relatively ignored (with some exceptions ${ }^{17}$ ). To assess the potential impacts of evening light exposure in shift workers, we conducted, to our knowledge, the first systematic review on the topic.

\section{Methods}

We searched eight databases relevant to sleep and circadian rhythms: Embase, Web of Science, MEDLINE, Cochrane Library, PsycINFO, ProQuest Central, OSF Preprints, and Europe PMC. Our search included randomised controlled trials ${ }^{41}$ that assessed the impact of light exposure on circadian-related outcomes during real or simulated shift work. We additionally searched for studies assessing jet lag, a related form of circadian misalignment. Table 1 shows the specific search terms which we translated

for each database. We also searched the relevant keywords in our own citation library. After a preliminary database search to assess feasibility, we registered the review online (https:/ / osf.io/z5yws).

We searched the databases on 2 Jun 2021, which returned 2,104 articles. After removing duplicate records by title using the metagear $\mathrm{R}$ package, ${ }^{42}$ a total of 1,187 unique articles remained.

Table 1: Search terms for MEDLINE which were adapted for other databases.

\begin{tabular}{ll}
\hline$\#$ & Search term \\
\hline 1 & melatonin*.mp. or Melatonin/ \\
2 & REM sleep.mp. or Sleep, REM/ \\
3 & Circadian Rhythm/ or Sleep Disorders, Circadian Rhythm/ or circadian*.mp. \\
4 & Jet Lag Syndrome/ or (jetlag* or "jet lag*").mp. \\
5 & Shift Work Schedule/ or shift*.mp. \\
6 & Phototherapy/ or phototherap*.mp.
\end{tabular}




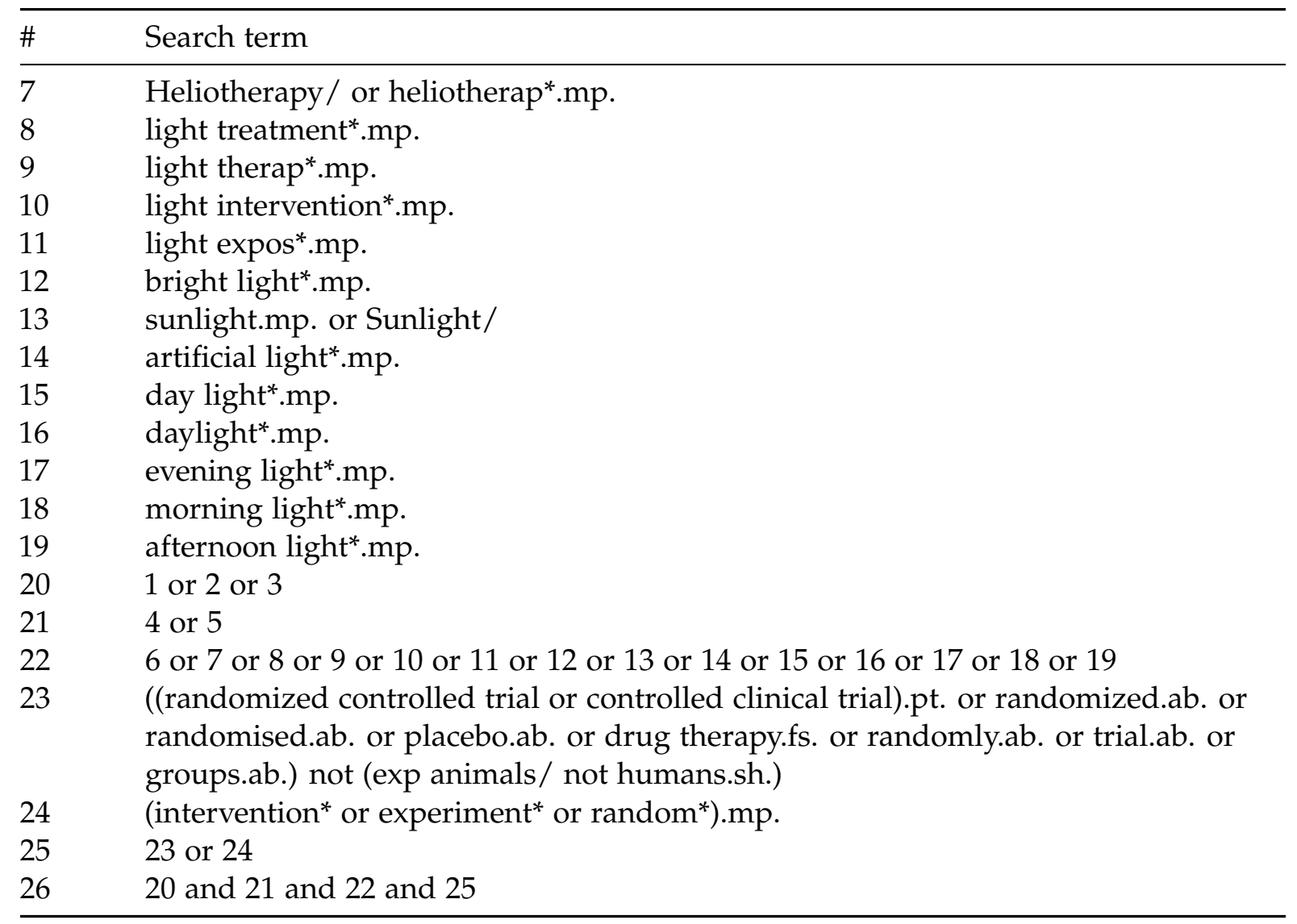

First, two raters screened each abstract to ensure it included human participants, used an experimental design, tested a real or simulated shift work paradigm (or travel across time zones), studied a healthy population, and manipulated light exposure. A total of 226 abstracts passed this screening phase.

Next, the two raters read each abstract (or article if necessary) and kept only those with bright light exposure in the evening; at least one biological, psychological, or behavioural outcome relevant to circadian rhythms; and at least one real or simulated night shift (or time zone crossing of at least $8 \mathrm{~h}$ ). We broadly defined bright light as light exposure above 100 lux to avoid excluding potentially relevant articles with varying definitions of brightness. Due to the variability of light sources available to shift workers, we did not exclude any light sources or types of light. The evening was broadly defined as between 16:00 and 22:00, capturing the earliest and latest sunset times across much of 
North America and Europe. ${ }^{43,44}$ This period typically falls within the delay portion of the human phase response curve. ${ }^{45}$ We chose biological, psychological, and behavioural outcomes relevant to circadian rhythms based on previous studies. ${ }^{5,21,26,46}$ Biological measures included physiological indicators of circadian phase, such as melatonin and body temperature. Psychological measures included well-being, mood, fatigue, depression, stress, anxiety, job-related quality of life, and work satisfaction. Behavioural measures included alertness, sleepiness, vigilance, cognition, work performance, absenteeism, and sick days. Finally, we operationalised night shifts as at least one night (minimum $8 \mathrm{~h}$ ) during which participants remained awake following the light exposure. Forty-five articles met these criteria.

Two raters then verified that none of the studies used light exposure ( $>100$ lux) past midnight in their evening light condition. Studies typically deliver bright light for several hours; with this midnight cut-off, we sought to include as many evening light interventions as possible while ensuring that the light exposure would not extend too far into the night. This cut-off also helped ensure that the bright light would primarily occur before the night shifts, which often begin after 22:00. ${ }^{47}$

The raters extracted the following data from the remaining six articles: country, season, setting, population, sample size, sex, age, light characteristics, study design, experimental conditions, outcome measures, and results. After the data extraction, one otherwise eligible article $^{48}$ was excluded because the comparison group was confounded by additional light exposure. This exclusion represented one of the three deviations from our registered protocol. Finally, we checked the reference lists of the five remaining articles which returned no additional eligible studies. Figure 1 summarises the screening process. 


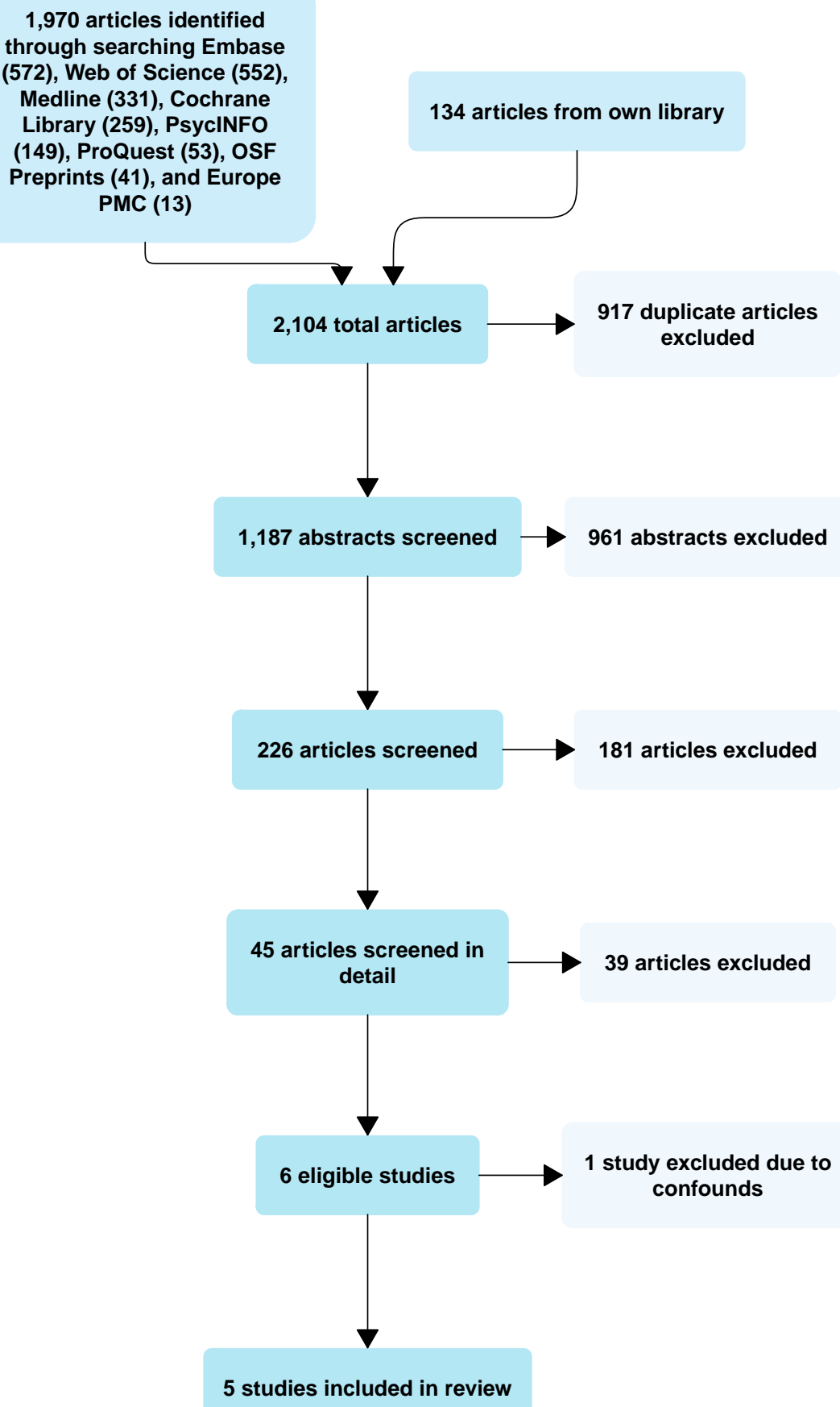

Figure 1: Study screening procedure. 


\section{Data analysis}

We used a narrative synthesis to summarise the findings; a meta-analysis was not possible due to the variety of interventions and outcomes. We grouped the results into five outcome categories relevant to the circadian rhythm literature or to shift workers: physiological indicators of circadian phase delay, sleep, sleepiness/fatigue, performance, and mood. This allowed us to combine conceptually related outcomes despite the heterogeneity of measures. Finally, as in other reviews, ${ }^{49,50}$ we categorised each finding as either favourable, unfavourable, or no impact. Each result was categorised based on statistical significance (e.g., $p<.05$ ); when the $p$ value was not reported, we used the authors' interpretation. Favourable meant that the finding was consistent with a phase delay (e.g., a later dim light melatonin onset) or had a positive acute effect (e.g., an increase in positive mood during the exposure). Unfavourable meant that the finding was consistent with a phase advance or had a negative acute effect. A finding was deemed as having no impact if there was no difference from the comparison group. Two raters classified the findings while a third resolved disagreements through discussion. The overall outcome category was deemed as favourable, unfavourable, or having no impact if at least two thirds of the interpretable findings received the same rating; otherwise, the category was rated as mixed.

\section{Quality of evidence}

We next assessed the quality of the evidence using the Grading of Recommendations, Assessment, Development, and Evaluations (GRADE) framework. ${ }^{51}$ Study findings were grouped by outcome category to determine quality. We assessed risk of bias according to the five recommended categories for randomised controlled trials: randomisation, allocation concealment, blinding, loss to follow-up, and selective outcome reporting. We also assessed the studies for large effects and the presence of a dose-response gradient. Finally, we assessed inconsistency, indirectness, imprecision, and publication 
bias. Evaluations were completed by two raters who resolved disagreements through discussion. Consistent with the GRADE framework, we also rated our confidence in the quality of the findings by consensus.

\section{Results}

\section{Samples}

There were 98 participants across the five studies, 85 of whom took part in our conditions of interest. Many of these participants (39\%) were from a single study of nurses working rapidly rotating shifts who had no diagnosed health conditions that could affect fatigue..$^{52}$ The rest of the sample was composed of healthy volunteers who were not shift workers. ${ }^{27,53-55}$ Participants ranged from 19 to $58 \mathrm{y}$ old, ${ }^{52,53}$ with the majority being under 35 . Half of the participants $(52 \%)$ were women, excluding one study $(n=8)$ which did not report sex. See Table 2 for additional study details.

Table 2: Study details. Values show mean $\pm \mathrm{SD} . \mathrm{BL}=$ bright light; $\mathrm{DL}=$ dim light.

\begin{tabular}{|c|c|c|c|c|c|c|c|c|}
\hline Authors & Country & Season & Setting & Population & Sample & Age (y) & Light time & Light source (lux) \\
\hline $\begin{array}{l}\text { Tzischinsky } \\
\text { \& Lavie, } \\
1997^{55}\end{array}$ & Israel & $\begin{array}{l}\text { Summer } \\
+ \\
\text { winter }\end{array}$ & $\begin{array}{l}\text { Lab + home } \\
\text { actigraphy }\end{array}$ & $\begin{array}{l}\text { Healthy } \\
\text { volunteers }\end{array}$ & $\begin{array}{l}12 \text { men }(11 \\
\text { completed } \\
\text { both } \\
\text { conditions) }\end{array}$ & $23.5 \pm 2.6$ & $\begin{array}{l}\text { Summer: } \\
\text { 20:00 to } \\
\text { 22:00 ( } n= \\
\text { 4), winter: } \\
\text { 19:00 to } \\
\text { 21:00 }(n=8)\end{array}$ & $\begin{array}{l}\text { Bright light } \\
\text { fixture; } B L=2500 \text {, } \\
D L=200\end{array}$ \\
\hline $\begin{array}{l}\text { Foret et } \\
\text { al., } 1998^{54}\end{array}$ & France & $\begin{array}{l}\text { Mar. and } \\
\text { Sep. }\end{array}$ & Lab only & $\begin{array}{l}\text { Healthy } \\
\text { volunteers }\end{array}$ & 8 men & 19 to 23 & $\begin{array}{l}20: 00 \text { to } \\
\text { midnight }\end{array}$ & $\begin{array}{l}\text { Ceiling fixture; BL } \\
=700 \text { to } 1000, \mathrm{DL} \\
=50\end{array}$ \\
\hline $\begin{array}{l}\text { Daurat et } \\
\text { al., } 2000^{53}\end{array}$ & France & $\begin{array}{l}\text { Oct. to } \\
\text { Mar. }\end{array}$ & Lab only & $\begin{array}{l}\text { Young } \\
\text { good } \\
\text { sleepers }\end{array}$ & $\begin{array}{l}8 \text { ( } 4 \text { per } \\
\text { condition) }\end{array}$ & 19 to 25 & $\begin{array}{l}\text { Experiment } \\
\text { B: 20:00 to } \\
\text { midnight }\end{array}$ & $\begin{array}{l}\text { Ceiling fixture; BL } \\
=2000, \mathrm{DL}<50\end{array}$ \\
\hline $\begin{array}{l}\text { Dumont et } \\
\text { al., 2009 }\end{array}$ & Canada & $\begin{array}{l}\text { May to } \\
\text { Sep. }\end{array}$ & $\begin{array}{l}\text { Home } \\
\text { (baseline) + } \\
\text { lab } \\
\text { (intervention) }\end{array}$ & $\begin{array}{l}\text { Healthy } \\
\text { volunteers }\end{array}$ & $\begin{array}{l}38 \text { (Delay } \\
\text { group: } 7 \\
\text { women, } 5 \\
\text { men; } \\
\text { Control: } 8 \\
\text { women, } 5 \\
\text { men; other } \\
\text { condition } \\
\text { not } \\
\text { relevant) }\end{array}$ & $\begin{array}{l}\text { Delay } \\
\text { group: } 26.7 \\
\pm 4.6 ; \\
\text { Control: } \\
26.6 \pm 4.2\end{array}$ & $\begin{array}{l}17: 00 \text { to } \\
23: 00\end{array}$ & $\begin{array}{l}\text { Ceiling light; } \mathrm{BL}= \\
1800, \text { Moderate = } \\
150 \text { to } 300, \mathrm{DL}= \\
20\end{array}$ \\
\hline
\end{tabular}




\begin{tabular}{|c|c|c|c|c|c|c|c|c|}
\hline Authors & Country & Season & Setting & Population & Sample & Age (y) & Light time & Light source (lux) \\
\hline $\begin{array}{l}\text { Olson et } \\
\text { al., } 2019^{52}\end{array}$ & Canada & $\begin{array}{l}\text { Not } \\
\text { reported }\end{array}$ & $\begin{array}{l}\text { Home (real- } \\
\text { world) }\end{array}$ & $\begin{array}{l}\text { Rapidly } \\
\text { rotating } \\
\text { shift } \\
\text { nurses }\end{array}$ & $\begin{array}{l}33 \text { ( } 25 \\
\text { women, } 8 \\
\text { men) }\end{array}$ & $\begin{array}{l}32.7 \pm 8.6 \\
(22 \text { to } 58)\end{array}$ & $\begin{array}{l}50.1 \pm 29.1 \\
\text { min, } \\
\text { commonly } \\
\text { around } \\
17: 00 \text { and } \\
\text { 18:00 } \\
\text { (before } \\
\text { 19:30 shifts) } \\
\text { or 22:00 } \\
\text { (before } \\
\text { 23:30 shifts) }\end{array}$ & $\begin{array}{l}\text { Portable light box; } \\
\mathrm{BL}=5500\end{array}$ \\
\hline
\end{tabular}

\section{Light exposure}

Our intervention of interest included bright light exposure (> 100 lux) at any point between 16:00 and 22:00 (but not beyond midnight) prior to a real or simulated night shift. Each bright light intervention was used either alone ${ }^{53-55}$ or in combination with other phase delaying strategies such as light avoidance or altered sleep times. ${ }^{27,52}$ The timing of the bright light varied from around 17:00 to midnight. One study ${ }^{55}$ adjusted the light exposure timing to the season, and one field study ${ }^{52}$ gave the light exposure before night shifts, which had different starting times. The duration of the light exposure also varied by study; the longest was $4 \mathrm{~h}$ from 20:00 to midnight ${ }^{53,54}$ and the shortest was an average of 50 minutes. ${ }^{52}$ The majority of studies used light fixtures with intensities ranging from 150 to 5,500 lux. Most of the interventions took place in a laboratory environment. See Tables 2 and 3 for details. 
Table 3: Study results. Values show mean $\pm \mathrm{SD}$. $\mathrm{BL}=$ bright light; $\mathrm{DL}=$ dim light; $\mathrm{REM}=$ rapid eye movement; $S A M=$ Search and Memory test.

\begin{tabular}{|c|c|c|c|c|c|}
\hline Authors & Design & Intervention & Comparison & Outcomes & Results \\
\hline $\begin{array}{l}\text { Tzischinsky } \\
\text { \& Lavie, } \\
1997^{55}\end{array}$ & $\begin{array}{l}2 \\
\text { conditions } \\
\text { (BL } \\
\text { vs. DL); } \\
\text { partici- } \\
\text { pants } \\
\text { assigned } \\
\text { in alter- } \\
\text { nating } \\
\text { order }\end{array}$ & $\begin{array}{l}2 \mathrm{~h} \text { evening BL for } \\
5 \mathrm{~d} \text {. On 5th day, } \\
\text { participants remained } \\
\text { awake until 07:00 the } \\
\text { following morning. } \\
\text { Began } 7 / 13 \text { sleep-wake } \\
\text { paradigm for } 72 \text { trials } \\
(24 \mathrm{~h}) \text { under DL }\end{array}$ & $\begin{array}{l}\text { Same } \\
\text { paradigm, but } \\
\text { DL instead of } \\
\text { BL }\end{array}$ & $\begin{array}{l}\text { Objective: } \\
\text { 1. Sleep propensity (PSG } \\
\text { recordings during each } \\
7 \text { min sleep attempt): } \\
\text { total amount of sleep } \\
\text { (stages } 1,2,3 / 4 \text {, and } \\
\text { REM) per } 7 \text { min trial } \\
\text { 2. Oral temperature } \\
\text { (measured every hour } \\
\text { with an ovulation } \\
\text { thermometer, after each } \\
7 \text { min sleep attempt) } \\
\text { Subjective: } \\
\text { 1. Mood (Global Vigor } \\
\text { and Affect [GVA]) } \\
\text { 2. Fatigue (GVA) } \\
\text { 3. Alertness (GVA) }\end{array}$ & $\begin{array}{l}\text { Objective: } \\
\text { 1. Phase delay of sleep } \\
\text { gate after BL from } 23: 04 \\
\pm 134 \text { min to } 23: 54 \pm \\
100 \text { min. In BL condition, } \\
\text { increased morning sleep } \\
\text { propensity (no statistics } \\
\text { provided). Between } 21: 00 \\
\text { and 23:00, BL increased } \\
\text { total sleep time relative } \\
\text { to DL. Between 21:00 and } \\
\text { 23:00, BL also increased } \\
\text { time spent in stage } 2 \\
\text { sleep relative to DL. } \\
\text { Interaction between time } \\
\text { of day and light } \\
\text { conditions for REM sleep } \\
\text { (no details provided). No } \\
\text { interaction for stage } 1 \text { or } \\
\text { 3/4 } \\
\text { 2. Oral temperature } \\
\text { acrophase: phase delay } \\
\text { from } 15: 28 \pm 100 \text { min to } \\
\text { 16:53 } \pm 150 \text { min } \\
\text { Subjective: } \\
\text { 1. Delay in the acrophase } \\
\text { of negative mood in BL } \\
\text { condition from } 01: 20 \pm \\
\text { 02:36 to } 03: 32 \pm 01: 38 \text {. No } \\
\text { change in positive mood } \\
\text { 2. No change in fatigue } \\
\text { 3. No change in alertness }\end{array}$ \\
\hline $\begin{array}{l}\text { Foret et } \\
\text { al., } \\
1998^{54}\end{array}$ & $\begin{array}{l}\text { Counter- } \\
\text { balanced } \\
\text { crossover; } \\
2 \\
\text { conditions } \\
\text { (BL from } \\
20: 00 \text { to } \\
\text { midnight } \\
\text { vs. } 04: 00 \\
\text { to } 08: 00 \text { ) }\end{array}$ & $\begin{array}{l}\text { Slept a normal night, } \\
\text { then awake for } 24 \mathrm{~h}: \\
\text { during the day ( } 08: 00 \text { to } \\
\text { 20:00) received natural } \\
\text { light through a } \\
\text { window, during the } \\
\text { first night (20:00 to } \\
\text { 08:00) remained awake } \\
\text { in DL except during the } \\
4 \mathrm{~h} \text { BL pulse (20:00 to } \\
\text { midnight). Slept during } \\
\text { the following day and } \\
\text { remained awake again } \\
\text { in DL from 20:00 to } \\
\text { 08:00 (second night) }\end{array}$ & $\begin{array}{l}\text { The DL period } \\
\text { of the 04:00 to } \\
08: 00 \text { BL } \\
\text { group for } \\
\text { night } 1 \text { only; } \\
\text { specifically, } \\
\text { from the start } \\
\text { of the day } \\
\text { (08:00) until } \\
\text { 03:59 (i.e., } \\
\text { right before } \\
\text { the start of the } \\
\text { 04:00 to 08:00 } \\
\text { BL) }\end{array}$ & $\begin{array}{l}\text { Objective: } \\
\text { 1. Rectal temperature } \\
\text { (monitored continuously } \\
\text { by a portable recorder) } \\
\text { 2. Cognitive performance } \\
\text { (SAM 1,3, and 5) } \\
\text { Subjective: } \\
\text { 1. Alertness (French } \\
\text { shortened version of the } \\
\text { Activation/Deactivation } \\
\text { Adjective Checklist) }\end{array}$ & $\begin{array}{l}\text { Objective: } \\
\text { 1. Night 1: 20:00 to } \\
\text { midnight BL did not } \\
\text { increase temperature in } \\
\text { comparison to DL } \\
\text { 2. Night 1: No effect of } \\
\text { time nor light condition } \\
\text { on SAM 1. Performance } \\
\text { on SAM } 3 \text { improved at } \\
\text { 23:30 by the 20:00 to } \\
\text { midnight BL. } \\
\text { Performance was } \\
\text { improved on SAM } 5 \text { at } \\
\text { 02:30 in the 20:00 to } \\
\text { midnight BL condition } \\
\text { Subjective: } \\
\text { 1. Night } 1: \text { No increase } \\
\text { in general activation } \\
\text { during the 20:00 to } \\
\text { midnight BL }\end{array}$ \\
\hline
\end{tabular}




\begin{tabular}{|c|c|c|c|c|c|}
\hline Authors & Design & Intervention & Comparison & Outcomes & Results \\
\hline $\begin{array}{l}\text { Daurat et } \\
\text { al., } \\
2000^{53}\end{array}$ & $\begin{array}{l}\text { Experiment } \\
\text { B: } \\
\text { between- } \\
\text { participants; } \\
2 \\
\text { conditions } \\
\text { (BL from } \\
\text { 20:00 to } \\
\text { midnight } \\
\text { vs. from } \\
\text { 04:00 to } \\
\text { 08:00) }\end{array}$ & $\begin{array}{l}\text { After one night of lab } \\
\text { recording (23:00 to } \\
\text { 07:00), participants } \\
\text { remained awake under } \\
\text { quasi-constant routine } \\
\text { during day and } \\
\text { following night. BL } \\
\text { from 20:00 to midnight } \\
\text { or from 04:00 to 08:00. } \\
\text { DL at all other times. } \\
\text { Participants remained } \\
\text { awake for } 24 \mathrm{~h} \text { the } \\
\text { following day }\end{array}$ & $\begin{array}{l}\text { The DL period } \\
\text { of the 04:00 to } \\
08: 00 \mathrm{BL} \\
\text { exposure } \\
\text { group; } \\
\text { specifically, } \\
\text { from the start } \\
\text { of } \\
\text { quasi-constant } \\
\text { routine until } \\
\text { 03:59 (i.e., } \\
\text { right before } \\
\text { the start of the } \\
\text { 04:00 to 08:00 } \\
\text { BL) }\end{array}$ & $\begin{array}{l}\text { Objective: } \\
\text { 1. Rectal temperature } \\
\text { (continuous recording) } \\
\text { 2. Serum melatonin } \\
\text { (radioimmunoassay; } \\
\text { blood samplings every } \\
2 \text { h from 20:00 to 08:00) } \\
\text { 3. Physiological } \\
\text { sleepiness (overnight } \\
\text { quantified EEG): theta } \\
\text { (4-8 Hz) to alpha } \\
\text { (8-12 Hz) power density } \\
\text { ratio } \\
\text { 4. Performance } \\
\text { (measured every } 3 \text { h } \\
\text { overnight): letter } \\
\text { cancellation, logical } \\
\text { reasoning, SAM 3, and } \\
\text { SAM } 5 \\
\text { Subjective: } \\
\text { 1. Sleepiness } \\
\text { (deactivation sleepiness; } \\
\text { Thayer's Adjective Check } \\
\text { List) } \\
\text { 2. Alertness (general } \\
\text { activation; Thayer's } \\
\text { Adjective Check List) } \\
\text { 3. Mood (POMS) }\end{array}$ & $\begin{array}{l}\text { Objective: } \\
\text { 2. Plasma melatonin } \\
\text { lower during 20:00 to } \\
\text { midnight BL relative to } \\
\text { DL } \\
\text { 3. The 20:00 to midnight } \\
\text { BL induced no difference } \\
\text { in theta band } \\
\text { 4. For letter cancellation, } \\
\text { SAM 3, and SAM 5, } \\
\text { speed was better during } \\
\text { BL. Logical reasoning } \\
\text { was measured but not } \\
\text { reported } \\
\text { Subjective: } \\
\text { 1. BL did not affect } \\
\text { sleepiness } \\
\text { 2. The 20:00 to midnight } \\
\text { BL showed no increase in } \\
\text { general activation } \\
\text { 3. Mood not reported }\end{array}$ \\
\hline
\end{tabular}




\begin{tabular}{|c|c|c|c|c|c|}
\hline Authors & Design & Intervention & Comparison & Outcomes & Results \\
\hline $\begin{array}{l}\text { Dumont } \\
\text { et al., } \\
2009^{27}\end{array}$ & $\begin{array}{l}\text { Between- } \\
\text { participants; } \\
3 \\
\text { conditions } \\
\text { (delay } \\
\text { vs. ad- } \\
\text { vance } \\
\text { vs. control) }\end{array}$ & $\begin{array}{l}5 \mathrm{~d} \text { at home, no } \\
\text { napping, with fixed } 8 \mathrm{~h} \\
\text { sleep episodes } \\
\text { determined by MEQ } \\
\text { score: } 23: 00 \text { to 07:00 } \\
\text { (morning types), 01:00 } \\
\text { to 09:00 (evening types), } \\
\text { or midnight to 08:00 } \\
\text { (neither type). Then, } \\
\text { one week in lab: } \\
\text { original fixed sleep } \\
\text { times for the first } \\
2 \text { nights (D2 to D3). DL } \\
\text { (under } 15 \text { lux) on day } 2 \text {, } \\
50 \text { lux on day 3, and } \\
\text { below } 2 \text { lux during } \\
\text { sleep. Simulated night } \\
\text { work from midnight to } \\
\text { 08:00 during the next } \\
4 \text { nights (D4 to D7; } \\
50 \text { lux during the first } \\
3 \text { nights and below } \\
\text { 15 lux on the fourth } \\
\text { night). Daytime sleep } \\
\text { from 09:00 to 17:00. } \\
\text { Daytime light profiles } \\
\text { the first } 3 \text { d of } \\
\text { simulated night work } \\
\text { (D4 to D6). Participants } \\
\text { were allowed } 3 \mathrm{~h} \text { sleep } \\
\text { in the middle of D7. DL } \\
\text { (<15 lux) on day } 2 \text { and } \\
\text { during the last } 24 \mathrm{~h} \text { in } \\
\text { the lab. Delay group: } \\
\text { moderate "outdoor" } \\
\text { light (400 lux) from } \\
08: 00 \text { to } 09: 00, \text { sleep } \\
\text { from 09:00 to 17:00, } \\
\text { moderate indoor light } \\
\text { (150 to } 300 \text { lux) from } \\
17: 00 \text { to } 23: 00, \text { and dim } \\
\text { light ( } 20 \text { lux) from } 23: 00 \\
\text { to midnight }\end{array}$ & $\begin{array}{l}\text { Stable group: } \\
\text { same } \\
\text { paradigm but } \\
\text { participants } \\
\text { received BL } \\
(1,800 \text { lux) } \\
\text { from 08:00 to } \\
\text { 09:00, slept } \\
\text { from 09:00 to } \\
\text { 17:00, had } \\
\text { moderate } \\
\text { indoor light } \\
\text { (150 lux) from } \\
\text { 17:00 to 20:00, } \\
\text { and had DL } \\
\text { (20 lux) from } \\
\text { 20:00 to } \\
\text { midnight }\end{array}$ & $\begin{array}{l}\text { Objective: } \\
\text { 1. Circadian phase } \\
\text { (salivary melatonin } \\
\text { measured every } 30 \mathrm{~min} \\
\text { during the } 6.5 \mathrm{~h} \\
\text { preceding bedtime on } \\
\text { day } 2 \text { and every } 30 \mathrm{~min} \\
\text { during the last } 24 \mathrm{~h} \text { in } \\
\text { the lab) } \\
\text { 2. Circadian phase } \\
\text { (urinary aMT6s excretion } \\
\text { measured every } 2 \mathrm{~h} \text { from } \\
\text { wake time on day } 2 \text { until } \\
\text { 22:00 on day } 7 \text {, except } \\
\text { during sleep episodes) }\end{array}$ & $\begin{array}{l}\text { Objective: } \\
\text { 1. The delay group } \\
\text { showed a phase delay } \\
(4.07 \mathrm{~h}) \text { in dim light } \\
\text { melatonin onset relative } \\
\text { to baseline by day } 7 \text {. This } \\
\text { delay was } 2.37 \mathrm{~h} \text { larger } \\
\text { than in the stable group } \\
\text { 2. The delay group } \\
\text { showed a phase delay in } \\
\text { urinary aMT6s relative to } \\
\text { baseline ( } 3.01 \mathrm{~h} \text { ) by } \\
\text { days } 6 \text { to } 7 \text {. This delay } \\
\text { was } 2.21 \mathrm{~h} \text { larger than in } \\
\text { the stable group }\end{array}$ \\
\hline
\end{tabular}




\begin{tabular}{|c|c|c|c|c|c|}
\hline Authors & Design & Intervention & Comparison & Outcomes & Results \\
\hline $\begin{array}{l}\text { Olson et } \\
\text { al., } \\
2019^{52}\end{array}$ & $\begin{array}{l}\text { Within- } \\
\text { participants; } \\
2 \\
\text { conditions } \\
\text { (baseline } \\
\text { then } \\
\text { intervention) } \\
\end{array}$ & $\begin{array}{l}2 \text { to } 4 \text { consecutive night } \\
\text { shifts (from } 19: 30 \text { to } \\
\text { 07:30 or } 23: 30 \text { to 07:30) } \\
\text { as well as the } 1 \text { or } 2 \mathrm{~d} \\
\text { before and after the } \\
\text { shifts. Day before first } \\
\text { night shift: } 1 \text { h delayed } \\
\text { bedtime and } 40 \text { min of } \\
\text { BL before bed. Day of } \\
\text { night shifts: slept in, } \\
\text { light avoidance } \\
\text { (sunglasses) after } \\
\text { waking, late nap (if } \\
\text { needed), and } 40 \text { min of } \\
\text { BL before work. After } \\
\text { night shifts: light } \\
\text { avoidance until sleep } \\
\text { and dark sleeping } \\
\text { environment. No } \\
\text { sunglasses after the } \\
\text { final night shift and } \\
\text { shortened sleep (to } \\
\text { transition back to day } \\
\text { shifts) }\end{array}$ & $\begin{array}{l}2 \text { to } 4 \\
\text { consecutive } \\
\text { night shifts as } \\
\text { well as the } 1 \\
\text { or } 2 \mathrm{~d} \text { before } \\
\text { and after } \\
\text { those shifts } \\
\text { without any } \\
\text { intervention }\end{array}$ & $\begin{array}{l}\text { Subjective: } \\
\text { 1. Fatigue (Daily Fatigue } \\
\text { Short Form) } \\
\text { 2. Sleepiness (Karolinska } \\
\text { Sleepiness Scale) } \\
\text { 3. Mood (International } \\
\text { Positive And Negative } \\
\text { Affect Schedule Short } \\
\text { Form) } \\
\text { 4. Sleep quality (Sleep } \\
\text { Quality Scale) } \\
\text { 5. Sleep duration (sleep } \\
\text { diary) } \\
\text { 6. Sleep latency } \\
\text { (self-report) } \\
\text { 7. Work-related errors } \\
\text { and near-errors } \\
\text { (self-report) }\end{array}$ & 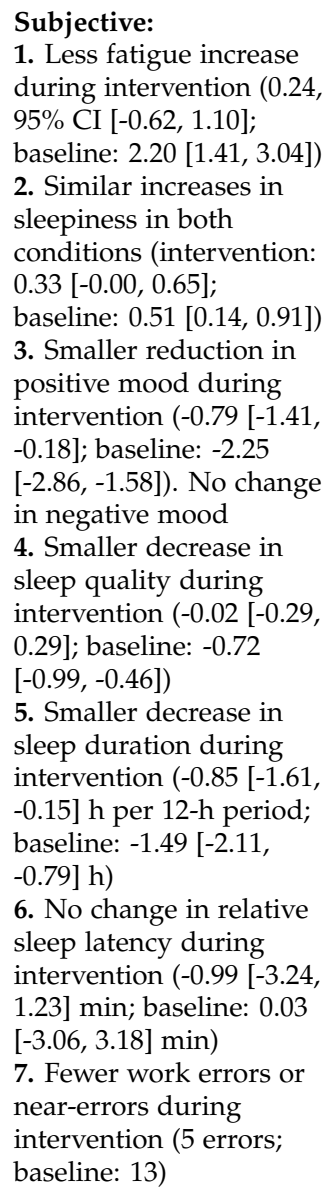 \\
\hline
\end{tabular}

\section{Comparison group}

We aimed to compare the bright light intervention to a condition that would allow us to isolate the effects of evening light alone or in combination with additional phase delaying strategies. Thus, our comparison of interest involved a condition in which participants were not exposed to any bright light in the evening (between 16:00 and 22:00). We made two exceptions to this criterion, which were the final two deviations from the registered protocol. One study used a dim light control condition with an intensity of 200 lux in the evening ${ }^{55}$ which would have matched our broad definition of bright light (> 100 lux). However, since their bright light condition was more intense (2,500 lux), we accepted the 200 lux as a valid comparison group. Another comparison group ${ }^{27}$ received light 
exposure (150 lux) from 17:00 to 20:00, which was meant to replicate typical daylight patterns and thus mimic a baseline condition. Again, because the intervention group received brighter light (300 lux), we accepted this baseline condition as a comparison group.

Three of the five studies used within-participant comparisons ${ }^{52,54,55}$ with washout periods ranging from one to approximately three weeks. The comparison groups included a baseline phase, ${ }^{52}$ a dim light condition,,$^{55}$ a combination of a baseline phase with a condition simulating typical light exposure patterns, ${ }^{27}$ and bright light given at a different time. ${ }^{53,54}$ For these last two studies, we only included data up until the start of the light exposure in the comparison group. Both comparison groups received light exposure from 04:00 to 08:00; excluding the data after 04:00 allowed us to isolate the effects of evening light.

\section{Outcomes}

See Table 3 for details regarding the outcome measures and results.

Physiological indicators of circadian phase delays Four of the five studies assessed phase delays using either body temperature, ${ }^{54,55}$ melatonin,,$^{27}$ or both. ${ }^{53}$ This was the only outcome category that included strictly objective measures and effect sizes for each outcome. Tzischinsky and Lavie ${ }^{55}$ found a phase delay in oral temperature, while Foret and colleagues ${ }^{54}$ found no change in rectal temperature. Daurat and colleagues ${ }^{53}$ found a reduction in plasma melatonin during the evening light exposure. Finally, relative to the baseline and control group, Dumont and colleagues ${ }^{27}$ reported a delay in the salivary dim light melatonin onset and in a urinary melatonin metabolite (aMT6s). Overall, we categorised the effects of evening light as favourable: $86 \%$ of the interpretable results showed a phase delay or a positive acute effect. 
Sleep Two of the studies assessed different aspects of sleep ${ }^{52,55}$ using self-report measures and physiological (EEG) assessments. Tzischinsky and Lavie ${ }^{55}$ found a phase delay of the sleep gate (i.e., the steepest increase in sleep propensity), increased morning sleep propensity, and increases in both stage 2 sleep and total sleep time between 21:00 and 23:00. However, they did not find differences in stage 1 nor stage 3/4 sleep. Olson and colleagues $^{52}$ found improvements in sleep quality and duration but no change in sleep latency. Overall, the effects of evening light on sleep were rated as favourable: $67 \%$ of the effects were beneficial while the rest had no impact.

Sleepiness/fatigue Four of the five studies measured sleepiness, alertness, or fatigue. Two studies assessed sleepiness using self-report ${ }^{52}$ or EEG, $^{53}$ three studies measured alertness (two of which used the same questionnaire), ${ }^{53-55}$ and two studies measured self-reported fatigue. ${ }^{52,55}$ Tzischinsky and Lavie ${ }^{55}$ found no change in alertness nor fatigue. Similarly, Daurat and colleagues ${ }^{53}$ reported no change in alertness during the light exposure and no impact on physiological or self-reported sleepiness. Foret and colleagues $^{54}$ likewise found no acute effect of evening light on alertness. Finally, although Olson and colleagues ${ }^{52}$ reported reductions in fatigue, they did not find a change in sleepiness. We thus concluded that evening light had no impact on this category: $88 \%$ of the outcomes showed no effect.

Performance Three studies assessed performance using laboratory or real-world measures. During evening light exposure, Daurat and colleagues ${ }^{53}$ found improvements in three memory and attention tasks (3-letter Search and Memory [SAM] task, 5-letter SAM task, and letter cancellation). Foret and colleagues ${ }^{54}$ also found improvements on the 3- and 5-letter SAM tasks, but no difference on the 1-letter version. Further, Olson and colleagues ${ }^{52}$ reported reductions in work-related errors. Overall, we concluded that evening light had a favourable impact on performance: $85 \%$ of the reported outcomes showed positive effects. 
Mood Two studies reported results for mood, which was measured using different questionnaires. ${ }^{52,55}$ This was the only category that included only subjective measures. Tzischinsky and Lavie ${ }^{55}$ found a phase delay in negative mood but no change in positive mood. In contrast, Olson and colleagues ${ }^{52}$ found an increase in positive mood but no change in negative mood. We therefore concluded that the effects on mood were mixed.

Quality of evidence The risk of bias was rated as very serious for all five outcomes. Inconsistency was low for all outcomes except mood, which was rated as high. No outcomes were downgraded for indirectness, whereas all outcomes were downgraded by one or two points for imprecision and publication bias. Our overall confidence in the results was moderate for physiological indicators of phase delay; low for sleep, sleepiness/fatigue, and performance; and very low for mood. See Tables S1 and S2 for more detail.

\section{Discussion}

Many shift workers experience circadian misalignment which can impact health and work performance. Bright light exposure at night can reduce this misalignment, though it is limited by feasibility and safety concerns. We investigated evening light as a potential alternative and conducted, to our knowledge, the first systematic review on the topic. Across five studies, we saw favourable outcomes for circadian phase delays, sleep, and performance. There were mixed effects for mood, no changes in sleepiness, and no negative effects. Overall, the benefits of evening light are tentative yet promising.

Physiological indicators Evening light produced phase delays as indicated by both melatonin and body temperature. These delays are consistent with experimental data of phase response curves. Light exposure can have a delaying effect starting around $3 \mathrm{~h}$ before the dim light melatonin onset, ${ }^{56}$ which normally occurs between 19:30 and 22:00. ${ }^{57}$ 
Given that the $3 \mathrm{~h}$ preceding this onset often occur in the evening, we would expect the light times included in our review to cause phase delays. This evidence also aligns with studies showing that light avoidance in the evening can reduce phase delays. ${ }^{58}$ Our confidence in this category of results was medium, making it the most robust in the review.

Sleep Evening light also had a favourable impact on sleep duration and quality. Other intervention studies using timed light exposure at night similarly found increases in sleep duration. ${ }^{22,59,60}$ The increase in subjective sleep quality is in line with studies showing objective increases in sleep efficiency from timed light exposure in shift workers. ${ }^{60}$ One study in our review also found a phase delay in sleep propensity, ${ }^{55}$ consistent with the delays seen in other physiological indicators. However, the variety of sleeprelated outcomes across the two relevant studies prevented us from drawing any general conclusions and our confidence remained low.

Sleepiness/fatigue We saw no effect on physiological or subjective sleepiness, while one study found a positive effect on fatigue. Light exposure at night has been shown to have positive effects in some studies ${ }^{61,62}$ but not in others. ${ }^{63}$ A Cochrane review found mixed and inconclusive results regarding the effects of night-time light on sleepiness and fatigue during the light exposure or the next day. ${ }^{64}$ It is therefore unclear which conditions are needed for the light exposure to be beneficial. For example, people may not be sufficiently sleepy in the evening to experience the immediate alerting effects of light exposure. ${ }^{53}$ Given the heterogeneity of the measures and the overall quality of the evidence, our confidence in these results was low.

Performance Evening light improved performance on both laboratory and real-world outcomes. This finding is consistent with other studies showing that bright light exposure during night shifts can improve performance on various laboratory tasks, ${ }^{65-67}$ although 
some negative effects such as increased motor errors have also been reported ${ }^{68}$ Overall, our confidence in these results was also low.

Mood Research has shown that both positive and negative affect follow a circadian rhythm. ${ }^{69}$ Since disruptions to either circadian rhythms or sleep can impair mood, $, 10,70$ improving these factors could theoretically be beneficial; ${ }^{10,70}$ however, the two studies in our review showed inconsistent results. Similarly mixed results have been found in studies of night-time light exposure. ${ }^{26,65,71,72}$ Due to the inconsistent findings and low quality of the evidence, our confidence in these results was very low.

\section{Implications and limitations}

Studies have shown that night-time light exposure followed by light avoidance in the morning can promote adaptation to night shifts.,17 Perhaps the largest benefit of evening light over night-time light exposure is its feasibility for shift workers. Receiving light at night would require institutional buy-in and light equipment at work, timing the light may require phase estimation of co-workers to prevent inadvertent phase advances, and the light equipment may need a separate area to avoid disturbing others. If evening light can promote phase delays to improve circadian alignment, receiving light exposure before a night shift (and avoiding light the next morning) could be a feasible and effective intervention for shift workers. ${ }^{52}$ Our review suggests that evening light may have at least some of the benefits of night-time light exposure.

Still, our results must be interpreted with caution. We had five eligible studies, only three of which directly studied circadian adaptation in the context of shift work. ${ }^{27,52}$ The studies were difficult to compare given that they varied in their outcomes, control groups, light duration, and light intensity. In addition, the light intensity was provided in lux

measured at the source rather than in melanopic lux; ${ }^{73}$ this newer measure better predicts circadian effects by quantifying how light is received on the retina. ${ }^{74}$ 
Further, we had a broad definition of evening light, ranging from 16:00 to 22:00 (provided that the light ended before midnight). Although the majority of the light exposure took place in the evening, the timing ranged from 17:00 to midnight, which made it difficult to isolate the impact of the evening light. In addition, all of the studies examined the effects of light exposure for under one week: two studied the same night as the light exposure, one had five days of evening light (along with morning light which may have counteracted some of the effects), and two studies looked at four consecutive night shifts. Longer periods of light exposure may have produced larger improvements, since light over several days can have additive effects. ${ }^{27}$ Finally, the studies were published over a span of two decades and therefore varied in their statistical practices and reporting. Few of the studies reported standardised effect sizes and confidence intervals, which made it difficult to compare the magnitude of the effects within our review or to other studies of night-time light exposure.

More broadly, consistent with the conclusions of the Working Time Society, ${ }^{17}$ it remains difficult to make general recommendations about light exposure to promote circadian adaptation in shift workers. Intentionally shifting circadian rhythms to and from night shifts may have unknown long-term health effects. For example, promoting circadian alignment through light exposure may have positive acute effects while potentially increasing circadian dysregulation over time.

\section{Future research}

Future studies should examine the safety of bright light in the evening versus at night. Night-time light exposure can lead to headaches, eye strain, and irritable mood; animal studies have also suggested that it can increase chronic disease. ${ }^{75}$ It is currently unknown whether evening light has similar drawbacks. Studies should also examine shift workers with sleep disorders, which we excluded because we were interested in the general 
effectiveness of evening light. Other studies have shown benefits in clinical populations; one study found that a combination of evening light and morning light avoidance improved sleep in nurses with clinical levels of insomnia. ${ }^{26}$ Similarly, studies should look at more demographically diverse populations given individual differences in sensitivity to evening light. ${ }^{76}$ Most of the participants in this review were under 35; one study had participants aged between 23 and 56 but the large majority were in their 20s and 30s. ${ }^{52}$ Because there is conflicting evidence about how circadian adaptation changes across the lifespan, ${ }^{77,78}$ it remains unclear which age groups could most benefit from evening light.

\section{Conclusion}

Given the broad consequences of shift work, it is important to find safe and feasible strategies to improve sleep and health. Evening bright light exposure appears to improve both objective and subjective outcomes that are relevant for shift workers, such as circadian adaptation, sleep, and performance. Evening light is thus a potentially promising solution that warrants further investigation.

\section{Practice points}

Evening bright light exposure may:

1. delay circadian rhythms to promote adaptation to night shifts,

2. improve sleep as well as performance on laboratory and real-world tasks, and

3. serve as a more feasible alternative to night-time light exposure.

\section{Research agenda}

Future research should:

1. isolate the effects of evening light from night-time light exposure, 
2. quantify the long-term benefits of evening light for shift workers,

3. assess any short- or long-term adverse effects, and

4. study demographically diverse healthy and clinical populations.

\section{References}

1. Centers for Disease Control and Prevention. Work organization characteristics (NHISOHS) charts. NIOSH Worker Health Charts [Internet]. 2015; Available from: https: / /wwwn.cdc.gov/NIOSH-WHC/chart/ohs-workorg/WORK?OU=WORKSCHD_R $\mathrm{CD} \& \mathrm{~T}=\mathrm{I} \& \mathrm{~V}=\mathrm{R} 2$

2. Williams C. Work-life balance of shift workers. Statistics Canada: Perspectives on Labour and Income. 2008;9(8):5-16.

3. Parent-Thirion A, Biletta I, Cabrita J, Llave OV, Vermeylen G, Wilczynska A, et al. 6th European working conditions survey: 2017 update. Publications Office of the European Union; 2017.

4. Oexman RD, Knotts TL, Koch J. Working while the world sleeps: A consideration of sleep and shift work design. Employee Responsibilities and Rights Journal [Internet]. 2002;14(4):145-57. Available from: https:// doi.org/10.1023\%2Fa\%3A1021189305076

*5. Smith MR, Eastman CI. Shift work: Health, performance and safety problems, traditional countermeasures, and innovative management strategies to reduce circadian misalignment. Nature and Science of Sleep [Internet]. 2012 Sep;111. Available from: https:// doi.org/10.2147\%2Fnss.s10372

6. Härmä M, Karhula K, Puttonen S, Ropponen A, Koskinen A, Ojajärvi A, et al. Shift work with and without night work as a risk factor for fatigue and changes in sleep length: A cohort study with linkage to records on daily working hours. Journal of Sleep Research [Internet]. 2018 Jan;28(3):e12658. Available from: https:/ / doi.org/10.1111\%2Fjsr.12658 
*7. James SM, Honn KA, Gaddameedhi S, Dongen HPAV. Shift work: Disrupted circadian rhythms and sleep - implications for health and well-being. Current Sleep Medicine Reports [Internet]. 2017 Apr;3(2):104-12. Available from: https://doi.org/10.1007\%2F s40675-017-0071-6

8. Kazemi R, Haidarimoghadam R, Motamedzadeh M, Golmohamadi R, Soltanian A, Zoghipaydar MR. Effects of shift work on cognitive performance, sleep quality, and sleepiness among petrochemical control room operators. Journal of Circadian Rhythms [Internet]. 2016 Feb;14(1). Available from: https://doi.org/10.5334\%2Fjcr.134

9. Killgore WDS. Effects of sleep deprivation on cognition. In: Progress in brain research [Internet]. Elsevier; 2010. pp. 105-29. Available from: https://doi.org/10.1016\%2Fb9 78-0-444-53702-7.00007-5

10. Watling J, Pawlik B, Scott K, Booth S, Short MA. Sleep loss and affective functioning: More than just mood. Behavioral Sleep Medicine [Internet]. 2016 May;15(5):394-409. Available from: https://doi.org/10.1080\%2F15402002.2016.1141770

11. Åkerstedt T, Wright KP. Sleep loss and fatigue in shift work and shift work disorder. Sleep Medicine Clinics [Internet]. 2009 Jun;4(2):257-71. Available from: https:/ / doi.or g/10.1016\%2Fj.jsmc.2009.03.001

12. Wagstaff AS, Lie J-AS. Shift and night work and long working hours - a systematic review of safety implications. Scandinavian Journal of Work, Environment \& Health [Internet]. 2011 Feb;37(3):173-85. Available from: https://doi.org/10.5271\%2Fsjweh. 3146

13. Lee ML, Howard ME, Horrey WJ, Liang Y, Anderson C, Shreeve MS, et al. High risk of near-crash driving events following night-shift work. Proceedings of the National Academy of Sciences [Internet]. 2015 Dec;113(1):176-81. Available from: https://doi.org/10.1073\%2Fpnas.1510383112 
14. Stutts JC, Wilkins JW, Osberg JS, Vaughn BV. Driver risk factors for sleep-related crashes. Accident Analysis \& Prevention [Internet]. 2003 May;35(3):321-31. Available from: https:/ / doi.org/10.1016\%2Fs0001-4575\%2802\%2900007-6

15. Brown DL, Feskanich D, Sanchez BN, Rexrode KM, Schernhammer ES, Lisabeth LD. Rotating night shift work and the risk of ischemic stroke. American Journal of Epidemiology [Internet]. 2009 Apr;169(11):1370-7. Available from: https:/ /doi.org/10 $.1093 \% 2 F a j e \% 2 F k w p 056$

16. Cordina-Duverger E, Menegaux F, Popa A, Rabstein S, Harth V, Pesch B, et al. Night shift work and breast cancer: A pooled analysis of population-based casecontrol studies with complete work history. European Journal of Epidemiology [Internet]. 2018 Feb;33(4):369-79. Available from: https:/ / doi.org/10.1007\%2Fs10654-018-0368-x

*17. Lowden A, Öztürk G, Reynolds A, Bjorvatn B. Working time society consensus statements: Evidence based interventions using light to improve circadian adaptation to working hours. Industrial Health [Internet]. 2019;57(2):213-27. Available from: https://doi.org/10.2486\%2Findhealth.sw-9

18. Bhadra U, Thakkar N, Das P, Bhadra MP. Evolution of circadian rhythms: From bacteria to human. Sleep Medicine [Internet]. 2017 Jul;35:49-61. Available from: https:/ / doi.org/10.1016\%2Fj.sleep.2017.04.008

19. Blume C, Garbazza C, Spitschan M. Effects of light on human circadian rhythms, sleep and mood. Somnologie [Internet]. 2019 Aug;23(3):147-56. Available from: https:/ / doi.org/10.1007\%2Fs11818-019-00215-x

20. Gooley JJ. Light resetting and entrainment of human circadian rhythms. In: Biological timekeeping: Clocks, rhythms and behaviour [Internet]. Springer India; 2017. pp. 297-313. Available from: https://doi.org/10.1007\%2F978-81-322-3688-7_14

21. Boivin DB, Boudreau P. Impacts of shift work on sleep and circadian rhythms. 
Pathologie Biologie [Internet]. 2014 Oct;62(5):292-301. Available from: https://doi.or g/10.1016\%2Fj.patbio.2014.08.001

22. Boivin DB, Boudreau P, James FO, Kin NMKNY. Photic resetting in night-shift work: Impact on nurses' sleep. Chronobiology international. 2012 Jun;29(5):619-28.

23. Suzuki K, Ohida T, Kaneita Y, Yokoyama E, Miyake T, Harano S, et al. Mental health status, shift work, and occupational accidents among hospital nurses in japan. Journal of Occupational Health [Internet]. 2004 Nov;46(6):448-54. Available from: https:/ / doi.org/10.1539\%2Fjoh.46.448

24. Boivin DB, James FO. Circadian adaptation to night-shift work by judicious light and darkness exposure. Journal of Biological Rhythms. 2002;17(6):556-67.

25. Crowley SJ, Lee C, Tseng CY, Fogg LF, Eastman CI. Complete or partial circadian re-entrainment improves performance, alertness, and mood during night-shift work. Sleep [Internet]. 2004 Sep;27(6):1077-87. Available from: https:/ / doi.org/10.1093\%2F sleep $\% 2 F 27.6 .1077$

*26. Huang L-B, Tsai M-C, Chen C-Y, Hsu S-C. The effectiveness of light/dark exposure to treat insomnia in female nurses undertaking shift work during the evening/night shift. Journal of Clinical Sleep Medicine. 2013;9(07):641-6.

27. Dumont M, Blais H, Roy J, Paquet J. Controlled patterns of daytime light exposure improve circadian adjustment in simulated night work. Journal of Biological Rhythms [Internet]. 2009 Sep;24(5):427-37. Available from: https:/ / doi.org/10.1177\%2F074873 0409343795

28. Chapdelaine S, Paquet J, Dumont M. Effects of partial circadian adjustments on sleep and vigilance quality during simulated night work. Journal of Sleep Research [Internet]. 2012 Feb;21(4):380-9. Available from: https://doi.org/10.1111\%2Fj.13652869.2012.00998.x 
29. Souman JL, Tinga AM, Pas SF te, Ee R van, Vlaskamp BNS. Acute alerting effects of light: A systematic literature review. Behavioural Brain Research [Internet]. 2018 Jan;337:228-39. Available from: https://doi.org/10.1016\%2Fj.bbr.2017.09.016

30. Elliott R, McKinley S, Cistulli P, Fien M. Characterisation of sleep in intensive care using 24-hour polysomnography: An observational study. Critical Care [Internet]. 2013;17(2):R46. Available from: https:/ / doi.org/10.1186\%2Fcc12565

31. Dugdale Z, Eiter B, Menéndez CC, Wong I, Bauerle T. Findings from a systematic review of fatigue interventions: Whats (not) being tested in mining and other industrial environments. American Journal of Industrial Medicine [Internet]. 2022 Feb; Available from: https:/ / doi.org/10.1002\%2Fajim.23334

32. Lack. Chronotype differences in circadian rhythms of temperature, melatonin, and sleepiness as measured in a modified constant routine protocol. Nature and Science of Sleep [Internet]. 2009 Nov;1. Available from: https://doi.org/10.2147\%2Fnss.s6234

33. Hansen J, Stevens RG. Case-control study of shift-work and breast cancer risk in danish nurses: Impact of shift systems. European Journal of Cancer [Internet]. 2012 Jul;48(11):1722-9. Available from: https:// doi.org/10.1016\%2Fj.ejca.2011.07.005

34. Russart KLG, Nelson RJ. Light at night as an environmental endocrine disruptor. Physiology \& Behavior [Internet]. 2018 Jun;190:82-9. Available from: https://doi.org/ 10.1016\%2Fj.physbeh.2017.08.029

35. Rybnikova NA, Haim A, Portnov BA. Does artificial light-at-night exposure contribute to the worldwide obesity pandemic? International Journal of Obesity [Internet]. 2016 Jan;40(5):815-23. Available from: https:// doi.org/10.1038\%2Fijo.2015.255

36. Figueiro MG, Radetsky L, Plitnick B, Rea MS. Glucose tolerance in mice exposed to lightdark stimulus patterns mirroring dayshift and rotating shift schedules. Scientific Reports [Internet]. 2017 Jan;7(1). Available from: https:/ / doi.org/10.1038\%2Fsrep40 
37. Opperhuizen A-L, Stenvers DJ, Jansen RD, Foppen E, Fliers E, Kalsbeek A. Light at night acutely impairs glucose tolerance in a time-, intensity- and wavelengthdependent manner in rats. Diabetologia [Internet]. 2017 Apr;60(7):1333-43. Available from: https:/ / doi.org/10.1007\%2Fs00125-017-4262-y

38. Blask DE, Brainard GC, Dauchy RT, Hanifin JP, Davidson LK, Krause JA, et al. Melatonin-depleted blood from premenopausal women exposed to light at night stimulates growth of human breast cancer xenografts in nude rats. Cancer Research [Internet]. 2005 Dec;65(23):11174-84. Available from: https:// doi.org/10.1158\%2F00 08-5472.can-05-1945

39. Dauchy RT, Xiang S, Mao L, Brimer S, Wren MA, Yuan L, et al. Circadian and melatonin disruption by exposure to light at night drives intrinsic resistance to tamoxifen therapy in breast cancer. Cancer Research [Internet]. 2014 Jul;74(15):4099110. Available from: https:// doi.org/10.1158\%2F0008-5472.can-13-3156

40. Min J-y, Min K-b. Outdoor light at night and the prevalence of depressive symptoms and suicidal behaviors: A cross-sectional study in a nationally representative sample of korean adults. Journal of Affective Disorders [Internet]. 2018 Feb;227:199-205. Available from: https://doi.org/10.1016\%2Fj.jad.2017.10.039

41. Glanville J, Kotas E, Featherstone R, Dooley G. Which are the most sensitive search filters to identify randomized controlled trials in MEDLINE? Journal of the Medical Library Association [Internet]. 2020 Oct;108(4). Available from: https://doi.org/10.5 195\%2Fjmla.2020.912

42. Lajeunesse MJ. Facilitating systematic reviews, data extraction and meta-analysis with the metagear package for R. Fitzjohn R, editor. Methods in Ecology and Evolution [Internet]. 2015 Oct;7(3):323-30. Available from: https://doi.org/10.1111\%2F2041- 


\section{0x.12472}

43. National Oceanic \& Atmospheric Administration. Sunset table for 2022 [Internet]. Global Monitoring Laboratory. 2022. Available from: https://gml.noaa.gov/grad/so lcalc $/$ table.php?lat=53.533 $/$ \&lon=-113.494 $/$ \&year $=2022$

44. Mira-Pérez J. The last sunset on mainland europe. Cartography and Geographic Information Science [Internet]. 2016 Nov;45(1):56-61. Available from: https://doi.or $\mathrm{g} / 10.1080 \% 2 \mathrm{~F} 15230406.2016 .1249409$

45. Khalsa SBS, Jewett ME, Cajochen C, Czeisler CA. A phase response curve to single bright light pulses in human subjects. The Journal of Physiology [Internet]. 2003 Jun;549(3):945-52. Available from: https:/ / doi.org/10.1113\%2Fjphysiol.2003.040477

46. Richter K, Acker J, Adam S, Niklewski G. Prevention of fatigue and insomnia in shift workers-a review of non-pharmacological measures. EPMA Journal [Internet]. 2016 Aug;7(1). Available from: https://doi.org/10.1186\%2Fs13167-016-0064-4

47. Garde AH, Hansen J, Kolstad HA, Larsen AD, Marie Hansen. How do different definitions of night shift affect the exposure assessment of night work? Chronobiology International [Internet]. 2016 Apr;33(6):595-8. Available from: https:/ / doi.org/10.310 9\%2F07420528.2016.1167729

48. Gil-Lozano M, Hunter PM, Behan L-A, Gladanac B, Casper RF, Brubaker PL. Short-term sleep deprivation with nocturnal light exposure alters time-dependent glucagon-like peptide-1 and insulin secretion in male volunteers. American Journal of Physiology-Endocrinology and Metabolism [Internet]. 2016 Jan;310(1):E41-50. Available from: https:/ / doi.org/10.1152\%2Fajpendo.00298.2015

49. Bolster L, Rourke L. The effect of restricting residents' duty hours on patient safety, resident well-being, and resident education: An updated systematic review. Journal of Graduate Medical Education [Internet]. 2015 Sep;7(3):349-63. Available from: 


\section{https://doi.org/10.4300\%2Fjgme-d-14-00612.1}

50. Patterson PD, Liszka MK, Mcilvaine QS, Nong L, Weaver MD, Turner RL, et al. Does the evidence support brief (<30-mins), moderate (31-60-mins), or long duration naps (61+ mins) on the night shift? A systematic review. Sleep Medicine Reviews [Internet]. 2021 Oct;59:101509. Available from: https://doi.org/10.1016\%2Fj.smrv.2021.101509

51. Guyatt G, Oxman AD, Akl EA, Kunz R, Vist G, Brozek J, et al. GRADE guidelines: 1. Introduction-GRADE evidence profiles and summary of findings tables. Journal of Clinical Epidemiology [Internet]. 2011 Apr;64(4):383-94. Available from: https: / / doi.org/10.1016\%2Fj.jclinepi.2010.04.026

52. Olson JA, Artenie DZ, Cyr M, Raz A, Lee V. Developing a light-based intervention to reduce fatigue and improve sleep in rapidly rotating shift workers. Chronobiology International [Internet]. 2019 Dec;37(4):573-91. Available from: https://doi.org/10.1 080\%2F07420528.2019.1698591

53. Daurat A, Foret J, Benoit O, Mauco G. Bright light during nighttime: Effects on the circadian regulation of alertness and performance. Neurosignals [Internet]. 2000;9(6):30918. Available from: https://doi.org/10.1159\%2F000014654

54. Foret J, Daurat A, Tirilly G. Effect of bright light at night on core temperature, subjective alertness and performance as a function of exposure time. Scandinavian Journal of Work, Environment \& Health. 1998;115-20.

55. Tzischinsky O, Lavie P. The effects of evening bright light on next-day sleep propensity. Journal of Biological Rhythms [Internet]. 1997 Jun;12(3):259-65. Available from: https:/ / doi.org/10.1177\%2F074873049701200307

*56. Hilaire MAS, Gooley JJ, Khalsa SBS, Kronauer RE, Czeisler CA, Lockley SW. Human phase response curve to a $1 \mathrm{~h}$ pulse of bright white light. The Journal of Physiology [Internet]. 2012 Jun;590(13):3035-45. Available from: https://doi.org/10.1113\%2Fjphy 
siol.2012.227892

57. Pandi-Perumal SR, Smits M, Spence W, Srinivasan V, Cardinali DP, Lowe AD, et al. Dim light melatonin onset (DLMO): A tool for the analysis of circadian phase in human sleep and chronobiological disorders. Progress in Neuro-Psychopharmacology and Biological Psychiatry [Internet]. 2007 Jan;31(1):1-11. Available from: https: / / doi.org/10.1016\%2Fj.pnpbp.2006.06.020

58. Hester L, Dang D, Barker CJ, Heath M, Mesiya S, Tienabeso T, et al. Evening wear of blue-blocking glasses for sleep and mood disorders: A systematic review. Chronobiology International [Internet]. 2021 May;38(10):1375-83. Available from: https:/ / doi.org/10.1080\%2F07420528.2021.1930029

59. Sasseville A, Hébert M. Using blue-green light at night and blue-blockers during the day to improves adaptation to night work: A pilot study. Progress in NeuroPsychopharmacology and Biological Psychiatry [Internet]. 2010 Oct;34(7):1236-42. Available from: https:/ / doi.org/10.1016\%2Fj.pnpbp.2010.06.027

60. Yoon I-Y, Jeong D-U, Kwon K-B, Kang S-B, Song B-G. Bright light exposure at night and light attenuation in the morning improve adaptation of night shift workers. Sleep [Internet]. 2002;25(3):351-6. Available from: https://doi.org/10.1093\%2Fsleep\%2F25.3 .351

61. Karchani M, Kakooei H, Yazdi Z, Zare M. Do bright-light shock exposures during breaks reduce subjective sleepiness in night workers? Sleep and Biological Rhythms [Internet]. 2011 Apr;9(2):95-102. Available from: https:// doi.org/10.1111\%2Fj.14798425.2011.00490.x

62. Dawson D, Campbell SS. Timed exposure to bright light improves sleep and alertness during simulated night shifts. Sleep [Internet]. 1991 Nov;14(6):511-6. Available from: https://doi.org/10.1093\%2Fsleep\%2F14.6.511 
63. Bjorvatn B, Pallesen S, Waage S, Thun E, Blytt KM. The effects of bright light treatment on subjective and objective sleepiness during three consecutive night shifts among hospital nurses a counter-balanced placebo-controlled crossover study. Scandinavian Journal of Work, Environment \& Health [Internet]. 2020 Oct;47(2):145-53. Available from: https:/ / doi.org/10.5271\%2Fsjweh.3930

*64. Slanger TE, Gross JV, Pinger A, Morfeld P, Bellinger M, Duhme A-L, et al. Persondirected, non-pharmacological interventions for sleepiness at work and sleep disturbances caused by shift work. Cochrane Database of Systematic Reviews [Internet]. 2016 Aug;2016(8). Available from: https://doi.org/10.1002\%2F14651858.cd010641.pu b2

65. Smith MR, Fogg LF, Eastman CI. Practical interventions to promote circadian adaptation to permanent night shift work: Study 4. Journal of Biological Rhythms [Internet]. 2009 Apr;24(2):161-72. Available from: https:/ / doi.org/10.1177\%2F0748730409332068

66. Motamedzadeh M, Golmohammadi R, Kazemi R, Heidarimoghadam R. The effect of blue-enriched white light on cognitive performances and sleepiness of night-shift workers: A field study. Physiology \& Behavior [Internet]. 2017 Aug;177:208-14. Available from: https://doi.org/10.1016\%2Fj.physbeh.2017.05.008

67. Kretschmer V, Schmidt K-H, Griefahn B. Bright light effects on working memory, sustained attention and concentration of elderly night shift workers. Lighting Research \& Technology [Internet]. 2011 Sep;44(3):316-33. Available from: https://doi.org/10.1 177\%2F1477153511418769

68. Griepentrog JE, Labiner HE, Gunn SR, Rosengart MR. Bright environmental light improves the sleepiness of nightshift ICU nurses. Critical Care [Internet]. 2018 Nov;22(1). Available from: https://doi.org/10.1186\%2Fs13054-018-2233-4

69. Emens JS, Berman AM, Thosar SS, Butler MP, Roberts SA, Clemons NA, et al. 
Circadian rhythm in negative affect: Implications for mood disorders. Psychiatry Research [Internet]. 2020 Nov;293:113337. Available from: https:/ / doi.org/10.1016\% 2Fj.psychres.2020.113337

70. Walker WH, Walton JC, DeVries AC, Nelson RJ. Circadian rhythm disruption and mental health. Translational Psychiatry [Internet]. 2020 Jan;10(1). Available from: https:/ / doi.org/10.1038\%2Fs41398-020-0694-0

71. Sletten TL, Raman B, Magee M, Ferguson SA, Kennaway DJ, Grunstein RR, et al. A blue-enriched, increased intensity light intervention to improve alertness and performance in rotating night shift workers in an operational setting. Nature and Science of Sleep [Internet]. 2021 May;Volume 13:647-57. Available from: https: / / doi.org/10.2147\%2Fnss.s287097

72. Boyce PR, Beckstead JW, Eklund NH, Strobel RW, Rea MS. Lighting the graveyard shift: The influence of a daylight-simulating skylight on the task performance and mood of night-shift workerst. Lighting Research and Technology [Internet]. 1997 Sep;29(3):105-34. Available from: https://doi.org/10.1177\%2F14771535970290030501

73. Lucas RJ, Peirson SN, Berson DM, Brown TM, Cooper HM, Czeisler CA, et al. Measuring and using light in the melanopsin age. Trends in Neurosciences [Internet]. 2014 Jan;37(1):1-9. Available from: https:/ / doi.org/10.1016\%2Fj.tins.2013.10.004

74. Brown TM. Melanopic illuminance defines the magnitude of human circadian light responses under a wide range of conditions. Journal of Pineal Research [Internet]. 2020 Apr;69(1). Available from: https://doi.org/10.1111\%2Fjpi.12655

*75. Navara KJ, Nelson RJ. The dark side of light at night: Physiological, epidemiological, and ecological consequences. Journal of Pineal Research [Internet]. 2007 Oct;43(3):21524. Available from: https:// doi.org/10.1111\%2Fj.1600-079x.2007.00473.x

76. Phillips AJK, Vidafar P, Burns AC, McGlashan EM, Anderson C, Rajaratnam SMW, 
et al. High sensitivity and interindividual variability in the response of the human circadian system to evening light. Proceedings of the National Academy of Sciences [Internet]. 2019 May;116(24):12019-24. Available from: https://doi.org/10.1073\%2Fpn as.1901824116

*77. Saksvik IB, Bjorvatn B, Hetland H, Sandal GM, Pallesen S. Individual differences in tolerance to shift work - a systematic review. Sleep Medicine Reviews [Internet]. 2011 Aug;15(4):221-35. Available from: https:/ / doi.org/10.1016\%2Fj.smrv.2010.07.002

*78. Burch JB, Tom J, Zhai Y, Criswell L, Leo E, Ogoussan K. Shiftwork impacts and adaptation among health care workers. Occupational Medicine [Internet]. 2009 Mar;59(3):159-66. Available from: https://doi.org/10.1093\%2Foccmed\%2Fkqp015 


\section{Supplementary tables}

Table S1: GRADE assessment. We interpreted the results based on the direction of the effects rather than the magnitude since effect sizes were rarely reported.

\begin{tabular}{|c|c|c|c|c|c|c|c|c|c|c|}
\hline Outcomes & $\begin{array}{l}\text { Initial } \\
\text { quality }\end{array}$ & $\begin{array}{r}\text { Risk } \\
\text { of bias }\end{array}$ & Inconsistency & Indirectness & Imprecision & $\begin{array}{c}\text { Publication } \\
\text { bias }\end{array}$ & Large effect & $\begin{array}{c}\text { Dose- } \\
\text { response }\end{array}$ & Total & Confidence \\
\hline $\begin{array}{l}\text { Physiological } \\
\text { phase delay }\end{array}$ & High & -2 & 0 & 0 & -1 & -1 & 0 & 0 & -4 & Moderate \\
\hline Sleep & High & -2 & 0 & 0 & -2 & -1 & 0 & 0 & -5 & Low \\
\hline $\begin{array}{l}\text { Sleepiness / } \\
\text { fatigue }\end{array}$ & High & -2 & 0 & 0 & -2 & -1 & 0 & 0 & -5 & Low \\
\hline Performance & High & -2 & 0 & 0 & -2 & -1 & 0 & 0 & -5 & Low \\
\hline Mood & High & -2 & -2 & 0 & -1 & -1 & 0 & 0 & -6 & Very low \\
\hline
\end{tabular}

Table S2: GRADE risk of bias assessment.

\begin{tabular}{|c|c|c|c|c|c|c|c|}
\hline Authors & Randomisation & $\begin{array}{l}\text { Allocation } \\
\text { concealment }\end{array}$ & t Blinding & $\begin{array}{l}\text { Loss to } \\
\text { follow-up }\end{array}$ & Selective outcome reporting & Other & Limitations \\
\hline $\begin{array}{l}\text { Tzischinsky } \\
\text { \& Lavie, } 1997\end{array}$ & Unclear & Unclear & No & $8.3 \%$ & Missing category search task & No & $\begin{array}{l}\text { Very } \\
\text { serious }\end{array}$ \\
\hline $\begin{array}{l}\text { Foret et al., } \\
1998\end{array}$ & Yes & Unclear & No & None & $\begin{array}{l}\text { Missing EEG and blood } \\
\text { sample results }\end{array}$ & No & $\begin{array}{l}\text { Very } \\
\text { serious }\end{array}$ \\
\hline $\begin{array}{l}\text { Daurat et al., } \\
2000\end{array}$ & Unclear & Unclear & No & None & $\begin{array}{l}\text { Missing mood and logical } \\
\text { reasoning }\end{array}$ & No & $\begin{array}{l}\text { Very } \\
\text { serious }\end{array}$ \\
\hline $\begin{array}{l}\text { Dumont et } \\
\text { al., } 2009\end{array}$ & No & No & Unclear & $5.3 \%$ & $\begin{array}{l}\text { Missing compliance with } \\
\text { sleep profiles }\end{array}$ & No & $\begin{array}{l}\text { Very } \\
\text { serious }\end{array}$ \\
\hline $\begin{array}{l}\text { Olson et al., } \\
2019\end{array}$ & No & No & No & $5.7 \%$ & $\begin{array}{l}\text { Missing step count (measure } \\
\text { was faulty) }\end{array}$ & $\begin{array}{l}\text { Unvalidate } \\
\text { outcome } \\
\text { measure }\end{array}$ & $\begin{array}{l}\text { Very } \\
\text { serious }\end{array}$ \\
\hline
\end{tabular}

